\title{
Association between Vitamin D Receptor Gene Polymorphisms with Immune Thrombocytopenic Purpura in Children Rafik Abdoelgader Salem ${ }^{1}$, Mohamed Ahmed Badr ${ }^{1}$, Tamer Hassan Mustafa ${ }^{1}$, Wafaa Abdelatief Emam ${ }^{2}$, Hala Mossad ${ }^{2}$ \\ Departments of ${ }^{1}$ Pediatric and ${ }^{2}$ Medical Biochemistry and Molecular Biology, Faculty of Medicine, Zagazig University, Egypt
}

Corresponding author: Rafik Abdoelgader Salem, Mobile: (+2)0100847142, Email: rafikkhpiza@gmail.com

\begin{abstract}
Background: Vitamin D receptor (VDR) gene polymorphisms have been demonstrated in the development of autoimmune diseases. Also, vitamin D deficiency has been linked with the development of autoimmune diseases. Immune thrombocytopenia purpura (ITP) is developed secondary to the production of autoantibodies against platelets leading to isolated thrombocytopenia. Objective: This study aimed to evaluate the association between VDR gene polymorphism and susceptibility to ITP in children as well as other prognostic factors. Patients and Methods: A casecontrol study included 60 subjects and conducted at Hematology Unit of Pediatric Department and Clinical Pathology Department at Zagazig University Hospital. Children were divided into: case group included 30 children with primary ITP and the control group included 30 matched healthy children 15 . All the included subjects were subjected to the following: history taking, physical examination, laboratory investigations. Results: There was no statistical significance difference between the studied groups regarding age or sex. Platelets count between the studied groups ranged from 6 to $38 \times 103 / \mathrm{mm}^{3}$ with mean $16.63 \pm 7.89$ and median $17 \times 103 / \mathrm{mm}^{3}$. There was no statistical significant relation between VDR BsmI gene polymorphism and sex, frequency of upper respiratory tract infection (URTI), purpura and ecchymosis; but there was a statistical significant increase in frequency of wet bleeding among BB genotype compared to other genotypes. There was no relation between VDR BsmI analysis and line of treatment among the studied cases group. Conclusion: VDR BsmI polymorphism can be used as a risk marker for ITP susceptibility in children. There was an association of VDR BsmI genotype frequency in ITP patients with no effect on platelet count or bleeding severity.

Keywords: Thrombocytopenia, Purpura VDR Bsmi, Vitamin D Receptor.
\end{abstract}

\section{INTRODUCTION}

Vitamin D is a steroid hormone precursor that undergoes chemical conversion in the liver and kidney: the first reaction produces 25 -hydroxyvitamin $\mathrm{D}$, an objective indicator of vitamin D status, and the second produces the main bioactive form, 1,25dihydroxyvitamin $\mathrm{D}$ (1). Vitamin $\mathrm{D}$ receptor polymorphisms are associated with the incidence and severity of certain autoimmune diseases ${ }^{(2)}$. The mechanism by which VDR polymorphism affects autoimmunity is not yet clear, although activation of the receptor contributes to immune responses via regulation of the T-helper (Th)1/Th2 cytokine balance and reduces production of Th2 cytokines ${ }^{(3)}$.

The immune thrombocytopenia purpura (ITP) in children is one of the most common benign hematologic disorders. Isolated, immune-mediated thrombocytopenia is characteristic of it (4). The etiology of thrombocytopenic purpura in the immune system is unclear but is likely due to genetic or acquired factors ${ }^{(5)}$.

Most frequently acquired factors are immunological problems such as cross-reactive antibodies to platelet membrane glycoproteins developed during viral infections such as rubella, varicella, mumps, cytomegalovirus, and Epstein-Barr viruses ${ }^{\left({ }^{(}\right)}$. These viral infections can trigger an autoimmune process leading to a loss of peripheral tolerance, and the production of self-reactive antibodies that destroy platelets. By modulating both innate and adaptive immunity, and regulating the inflammatory cascade, vitamin D has a significant influence on the host's immune system ${ }^{(7)}$.

In recent years $1,25 \quad[\mathrm{OH}] 2 \mathrm{D} 3$ has been rediscovered as an immune modulator. Lassandro et al. ${ }^{(8)}$ suggested that vitamin D deficiency does not represent a chronicity factor for ITP. So, further studies are needed to understand the role of vitamin D in ITP pathogenesis.

The current study aimed to evaluate the association between VDR gene polymorphism and susceptibility to ITP in children as well as other prognostic factors.

\section{PATIENTS AND METHODS}

A case-control study included 60 subjected and conducted at Hematology Unit of Pediatric Department and Clinical Pathology Department at Zagazig University Hospital during a period from December 2020 to the end of May 2021.

Inclusion criteria: Children with primary ITP, both sexes, and age between 1 - 15 years.

Exclusion criteria: Children with other causes of thrombocytopenia, children $<1$ year and $>15$ years, and children with recent manifestations of active infection, or secondary causes of ITP. 


\section{Operating design:}

The participants were divided equally into: case group (30 children) with primary ITP, and control group (30 children). The diagnosis of ITP was made on the basis of proper assessment of history, with special attention to the history of intake of medications known to cause thrombocytopenia and symptoms suggesting associated viral infections.

All patients were subjected to history of drug intake such as steroids that nearly most of patients conservative pr started by oral steroid at first and shifted to other line regimen of treatment such as intravenous immunoglobulins (IVIG) or started plus IVIG or poor response and history of bleeding (skin, URTI, purpura, ecchymosis, or mucus membrane, frank bleeding).

Laboratory investigations included complete blood count (CBC), reticulocyte count, peripheral blood smears, and direct antiglobulin test, aPTT, bleeding time, and clotting time and stool for $\mathrm{H}$ pylori antigen. Bone marrow examination, actually we did not need to do this invasive procedure to our patients as their presentations, clinical scenarios, and laboratory investigations went smoothly for ITP diagnosis.

\section{VDR polymorphisms detection:}

VRD BsmI polymorphism (rs1544410) was detected by polymorphism reaction (PCR) followed by restriction fragment length polymorphism analysis (PCR-RFLP). One milliliter peripheral venous blood samples were collected in sterile tubes containing EDTA for DNA extraction. DNA was extracted from wholeblood samples using QIA amp Blood Genomic DNA Kit catalog number: K0781 (USA). For determining DNA concentration, 1 OD unit measured at $260 \mathrm{~nm}$ corresponds to $50 \mu \mathrm{g} / \mathrm{ml}$ of DNA.DNA purity was determined by measuring the A260/A280 ratio. For statistical analysis, capital letters represented absence and lowercase letters represented the presence of BsmI restriction site; (B/b). Genotype was determined according to fragments length i.e. homozygote AA (bb) subjects $=822 \mathrm{bp}$ product, heterozygote $\mathrm{GA}(\mathrm{Bb})$ subjects $=822,650$ and $172 \mathrm{bp}$ products and homozygote subjects $\mathrm{GG}(\mathrm{BB})=650$ and $172 \mathrm{bp}$ product. SNP resulting in A$G$ substitution in VDR gene intron 8 leads to the generation of a BsmI restriction site. Homozygous subjects with alleles containing nucleotide $\mathrm{A}$ at this position showed one band at $822 \mathrm{bp}$ and were designated as having bb BsmI genotype. Homozygous subjects with alleles containing $\mathrm{G}$ at this position showed 2 bands of 650 and $172 \mathrm{bp}$ and were designated as BB. Subjects with heterozygote status showed 3 bands: 825, 650, and $172 \mathrm{bp}$ and was designated $\mathrm{Bb}$.

\section{Ethical approval:}

The study was approved by the Ethical Committee of Zagazig Faculty of Medicine. An informed consent was obtained from the caregivers of all patients in this research. Every patient received an explanation for the purpose of the study. All given data were used for the current medical research only. This work has been carried out in accordance with The Code of Ethics of the World Medical Association (Declaration of Helsinki) for studies involving humans.

\section{Statistical Analysis}

Data were analyzed using SPSS (statistical package for the social sciences) program version 21 for windows and Epi-Info program version for all the analysis. Chi-square $\chi^{2}$ test, Fischer exact test, MannWhitney test, and Kruskal-Wallis test were done. All data were tested with Kolmogorov- Smirnov $\mathrm{Z}$ test and so presented with mean $\pm \mathrm{SD}$, median and interquartile range (IQR). $\mathrm{P}$ value $<0.05$ was considered significant.

\section{RESULTS}

There was no significant difference between both groups regarding age and gender (Table 1).

Table (1): Demographic data of the studied groups

\begin{tabular}{|c|c|c|c|c|c|c|}
\hline Variable & \multicolumn{2}{|c|}{$\begin{array}{l}\text { Patients } \\
(\mathbf{n}=\mathbf{3 0})\end{array}$} & \multicolumn{2}{|c|}{$\begin{array}{c}\text { Controls } \\
(\mathbf{n}=\mathbf{3 0})\end{array}$} & MW & $\mathbf{P}$ value \\
\hline $\begin{array}{l}\text { Age: }(\text { years) } \\
\text { Mean } \pm \text { SD } \\
\text { Range } \\
\text { Median (IQR) }\end{array}$ & \multicolumn{2}{|c|}{$\begin{array}{c}8.73 \pm 3.02 \\
4-14 \\
9(6-11)\end{array}$} & \multicolumn{2}{|c|}{$\begin{array}{c}8.33 \pm 3.62 \\
3-14 \\
8.5(5-11.25)\end{array}$} & 0.42 & $\begin{array}{c}0.67 \\
\text { NS }\end{array}$ \\
\hline \multirow[b]{2}{*}{$\begin{array}{l}\text { Sex: } \\
\quad \text { Female } \\
\quad \text { Male }\end{array}$} & No & $\%$ & No & $\%$ & $\chi^{2}$ & \multirow[b]{2}{*}{$\begin{array}{c}0.80 \\
\text { NS }\end{array}$} \\
\hline & $\begin{array}{l}16 \\
14\end{array}$ & $\begin{array}{l}53.3 \\
46.7\end{array}$ & $\begin{array}{l}15 \\
15\end{array}$ & $\begin{array}{l}50 \\
50\end{array}$ & 0.07 & \\
\hline
\end{tabular}

SD: Standard deviation IQR: Inter quartile range MW: Mann Whitney test $\chi^{2}$ : Chi square test

The proceeding factor of URTI was found in $46.7 \%$, of our patients (Figure 1). 


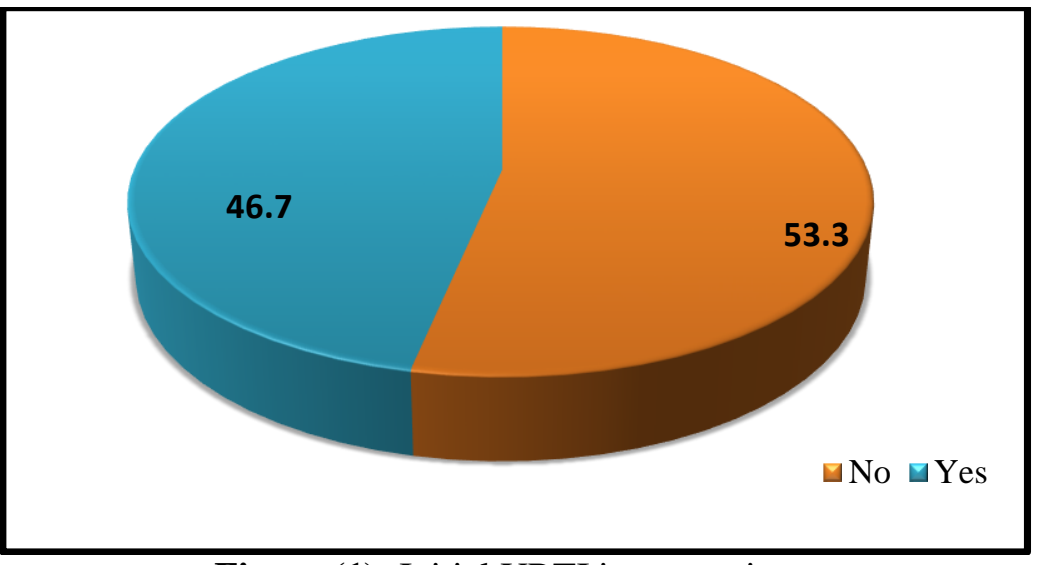

Figure (1): Initial URTI in our patients

The most common clinical presentation in our patients was purpura (Table 2).

Table (2): Initial clinical presentation in our patients

\begin{tabular}{|l|c|c|}
\hline \multirow{2}{*}{ Variable } & \multicolumn{2}{|c|}{ Patients $(\mathbf{n = 3 0})$} \\
\cline { 2 - 3 } & No & \% \\
\hline Purpura: & 24 & 80 \\
Yes & 6 & 20 \\
No & 22 & \\
Ecchymosis: & 8 & 73.3 \\
Yes & & 26.7 \\
No & 11 & \\
Wet bleeding: & 19 & 36.7 \\
Yes & & 63.3 \\
No & \\
\hline
\end{tabular}

Regarding VDR BsmI analysis, the three Cdx-2 genotype distributions in the participants, these results illustrated that in the patient's, the most presented genotype was the BB genotype. While in the control group the BB genotype was presented (Figure 2).

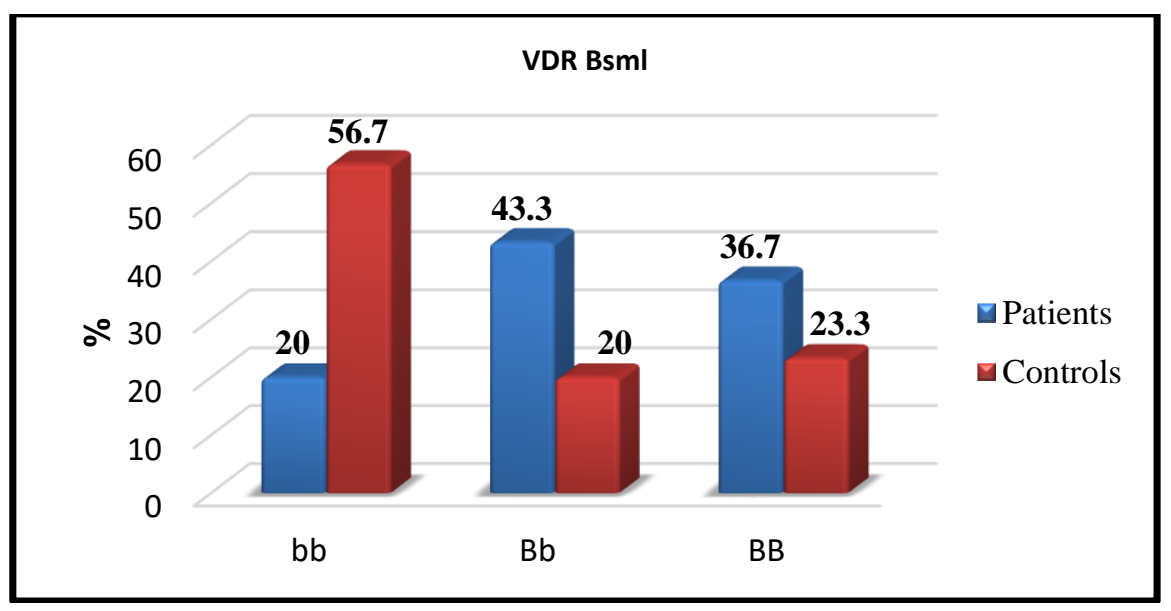

Figure (2): Comparison of VDR BsmI analysis between our patients.

There was no relation between VDR BsmI analysis and initial platelets count between our patients (Table 3).

Table (3): Relation between VDR BsmI analysis and initial platelets count between our patients

\begin{tabular}{|c|c|c|c|c|c|}
\hline \multirow{2}{*}{ Variable } & \multirow{2}{*}{ No } & \multicolumn{2}{|c|}{ Platelets $\left(\mathrm{x} 10^{3} / \mathrm{mm}^{3}\right)$} & \multirow{2}{*}{ KW } & \multirow{2}{*}{$P$ value } \\
\hline & & Median & IQR & & \\
\hline $\begin{array}{r}\text { Gene: } \\
\mathrm{bb} \\
\mathrm{Bb} \\
\mathrm{BB}\end{array}$ & $\begin{array}{c}6 \\
13 \\
11\end{array}$ & $\begin{array}{c}13.5 \\
18 \\
10\end{array}$ & $\begin{array}{c}10-21.5 \\
12-23 \\
10-19\end{array}$ & 3.01 & $\begin{array}{c}0.22 \\
\text { NS }\end{array}$ \\
\hline
\end{tabular}

IQR: Inter quartile range, KW: Kruskal Wallis test

There was no relation between VDR BsmI analysis and $1^{\text {st }}$ line of treatment between our patients (Table 4). 
Table (4): Relation between VDR BsmI analysis and $1^{\text {st }}$ line of treatment between our patients

\begin{tabular}{|c|c|c|c|c|c|c|c|c|}
\hline \multirow[t]{2}{*}{ Variable } & \multicolumn{2}{|c|}{$\begin{array}{c}\text { bb } \\
(n=)\end{array}$} & \multicolumn{2}{|c|}{$\begin{array}{c}\text { Bb } \\
(n=30)\end{array}$} & \multicolumn{2}{|c|}{$\begin{array}{c}\text { BB } \\
(n=)\end{array}$} & \multirow[t]{2}{*}{$\chi^{2}$} & \multirow[t]{2}{*}{$\mathbf{P}$} \\
\hline & No & $\%$ & No & $\%$ & No & $\%$ & & \\
\hline Conservative $(n=4)$ & 1 & 25 & 3 & 75 & 0 & 0 & \multirow{4}{*}{8.57} & \multirow{4}{*}{$\begin{array}{c}0.20 \\
\mathrm{NS}\end{array}$} \\
\hline Steroid $\quad(n=11)$ & 3 & 27.3 & 6 & 54.5 & 2 & 18.2 & & \\
\hline IVGF $\quad(n=5)$ & 0 & 0 & 2 & 40 & 3 & 60 & & \\
\hline Steroid+IVGF $(n=10)$ & 2 & 20 & 2 & 20 & 6 & 60 & & \\
\hline
\end{tabular}

$\chi^{2}$ : Chi square test

\section{DISCUSSION}

Concerning immune thrombocytopenia, there are no published reports available in the literature on the association of VDR gene polymorphisms in children ITP patients. Primary ITP is a complex, chronic, often cell-specific, autoimmune disease that is still not fully understood. It is defined currently as isolated thrombocytopenia (peripheral blood platelet count $\left.<100 \times 10^{9} / 1\right)$ in the absence of conditions known to cause thrombocytopenia ${ }^{(9)}$. It is caused by an inappropriate response of the immune system usually following a viral infection or immunization ${ }^{(10)}$. In ITP the autoantibodies are directed against the individual's own platelets, resulting in increased $\mathrm{Fc}$-mediated platelet destruction by macrophages in the reticuloendothelial system ${ }^{(11)}$.

As ITP had been testified to be a heterogeneous disease, studies in terms of gene polymorphisms in ITP are being carried out extensively, and new findings and opinions are continually being published ${ }^{(\mathbf{1 2})}$, which are helpful to better understand the pathogenesis of ITP and would be of value in choosing therapeutic regimens.

Our study included 30 subjects. They were 16 $(53.3 \%)$ females and 14 (46.7\%) males with mean age of $8.73 \pm 3.02$ years, and control group include 30 matched healthy children $15(50 \%)$ females and 15 $(50 \%)$ males with mean age of $8.33 \pm 3.62$ years. There was no significant difference between both group regarding age and sex as our study was designed to choose cross matched participants for age and sex. However, previous studies reported a higher male/female ratio during infancy with a decreasing trend toward older age ${ }^{(\mathbf{1 3})}$.

Our results goes with Evim et al. (14) who reported in their study on 201 children to evaluate the data of children with ITP by using the new definitions of the International Working Group (IWG) on ITP, that the most frequent symptoms were ecchymosis (71\%).

Grimaldi-Bensouda et al. ${ }^{(15)}$ reported in their study on 257 children aged 6 months -18 years and diagnosed with primary ITP, $208(80.9 \%)$ patients started initial treatment while the other $49(19.1 \%)$ underwent watchful waiting strategy. Of the 208 patients, 63/208 (30.3\%) were initially treated with corticosteroids alone, 99/208 (47.6\%) were initially treated with IVIG alone while 46/208 (22.1\%) were initially treated with corticosteroids and IVIG. On the other hand, the study of Hesham et al. ${ }^{(16)}$ reported $100 \%$ (20 patients) were given oral steroids and solumedrol, 65\% (13 patients) were given IVIG and only 6 patients $(30.0 \%)$ were given thrombopoietin receptor agonists.

Monticielo et al. ${ }^{(17)}$ demonstrated that the level of VDR mRNA was significantly decreased in patients with the VDR $B$ allele versus those not bearing the $B$ allele. To date, a large number of studies regarding the association between BsmI gene polymorphism and autoimmune diseases have been published. Moreover, in case group, BsmI B allele frequency was $58.3 \%$ and that for $\mathrm{b}$ allele was $41.7 \%$. However, in control group, BsmI B allele frequency was $33.3 \%$ and that for $\mathrm{b}$ allele was $66.7 \%$. This goes with Abd-Allah et al. ${ }^{(18)}$, El-Barbarya et al. ${ }^{\left({ }^{(9)}\right)}$ and Elhoseiny et al. ${ }^{(20)}$, but not in agreement with Mansour et al. ${ }^{(21)}$, Emerah and ElShal ${ }^{(22)}$, Mosaad et al. ${ }^{(23)}$, and Saad et al. ${ }^{(24)}$. This difference might be related the size of each study.

The present study shows that there was no relation between VDR BsmI analysis and line of treatment among the studied cases group. This result goes with the study of Evim et al. ${ }^{(14)}$ and Hesham $\boldsymbol{e t}$ al. ${ }^{(16)}$.

\section{CONCLUSION}

VDR BsmI polymorphism can be used as a risk marker for ITP susceptibility in children. There was an association of VDR BsmI genotype frequency in ITP patients with no effect on platelet count or bleeding severity.

Financial support and sponsorship: Nil. Conflict of interest: Nil.

\section{REFERENCES}

1. Baeke F, Takiishi T, Korf $H$ et al. (2010): Vitamin D modulator of the immune system. Curr Opin Pharmacol., 10:482-496.

2. Inoue $N$, Watanabe $M$, Ishido $N$ et al. (2014): The functional polymorphisms of VDR, GC and CYP2R1 are involved in the pathogenesis of autoimmune thyroid diseases. Clin Exp Immunol., 178: 262-269.

3. Vasileiou E, Simpson C, Shi T et al. (2021): Interim findings from first-dose mass COVID-19 vaccination roll-out and COVID-19 hospital admissions in Scotland: a national prospective cohort study. Lancet, 397(10285): 1646-1657. 
4. Cooper N, Bussel J (2006): The pathogenesis of immune thrombocytopaenic purpura. Br J Haematol., 133: 364-74.

5. Cines D, Bussel J, Liebman $H$ et al. (2009): The ITP syndrome: Pathogenic and clinical diversity. Blood, 113: 6511-21.

6. Lanzkowsky P, Lipton J, Fish J (2016): Lanzkowsky’s Manual of Pediatric Hematology and Oncology, $6^{\text {th }}$ edn. Academic Press, London, Pp. 788. https://www.elsevier.com/books/lanzkowskys-manualof-pediatric-hematology-and-oncology/fish/978-0-12801368-7

7. Handel A, Sandve G, Disanto G et al. (2013): Vitamin D receptor ChIP-seq in primary CD4+ cells: Relationship to serum 25-hydroxyvitamin D levels and autoimmune disease. BMC Med., 163: 1-11.

8. Lassandro G, Carriero F, Palmieri V et al. (2020): Serum vitamin D levels in children with immune thrombocytopenia. Endocrine, Metabolic \& Immune Disorders - Drug Targets, 20, (2): 221-226

9. Provan D, Stasi R, Newland A et al. (2010): International consensus report on the investigation and management of primary immune thrombocytopenia. Blood, 115: 168-186.

10.Rehman A (2007): Acute immune thrombocytopenic purpura in children. Turkish Journal of Hematology, 28:41-48.

11.Kara-Jovanović A, Suvajdžić-Vuković N (2020): Clinical presentation and therapy of primary immune thrombocytopenia resistant to splenectomy. International Journal of Medical Students, 8 (1): 11-14.

12. Buchanan G (2014): Immune thrombocytopenia during childhood: New Approaches to Classification and Management. J Pediatrics, 165 (3) 437-439

13.Liebman H, Pullarkat V (2011): Diagnosis and management of immune thrombocytopenia in the era of thrombopoietin mimetics. Hematology Am Soc Hematol Educ Program, 2011:384-390.

14. Evim M, Baytan B, Güneş A (2014): Childhood immune thrombocytopenia: Long-term follow-up data evaluated by the criteria of the international working group on immune thrombocytopenic purpura. Turk J
Haematol., 31 (1): 32-39

15.Grimaldi-Bensouda L, Nordon C, Leblanc $T$ et al. (2017): Childhood immune thrombocytopenia: A nationwide cohort study on condition management. Pediatr Blood Cancer, 17: 1-8.

16.Hesham M, Sherif L, Abd-Elmaaguid A et al. (2020): Vitamin D receptor polymorphisms in children with chronic immune thrombocytopenic purpura. The Egyptian Journal of Hospital Medicine, 80(2): 767-772.

17. Monticielo O, Brenol J, Chies J et al. (2012): The role of BsmI and FokI vitamin D receptor gene polymorphisms and serum 25-hydroxyvitamin $\mathrm{D}$ in Brazilian patients with systemic lupus erythematosus. Lupus, 21: 43-52.

18. Abd-Allah S, Pasha H, Hagrass H et al. (2014): Vitamin D status and vitamin D receptor gene polymorphisms and susceptibility to type 1 diabetes in Egyptian children. Gene, 536:430-34.

19.El-Barbarya A, Husseinb M, Ragehb E et al. (2015): Vitamin D receptor gene polymorphism in rheumatoid arthritis and its association with atherosclerosis. Egypt Rheumatol Rehabil., 42:145-52.

20. Elhoseiny S, Morgan D, Rabie A et al. (2016): Vitamin D Receptor Gene Polymorphisms (FokI, BsmI) and their Relation to Vitamin D Status in Pediatrics beta Thalassemia Major. Indian J Hematol Blood Transfus., 32(2):228-38.

21. Mansour L, Sedky M, Abdel Khader M et al. (2010): The role of vitamin D receptor genes (FOKI and BSMI) polymorphism in osteoporosis. Middle East Fertility Society Journal, 15:79-83.

22.Emerah A, El-Shal A (2013): Role of vitamin D receptor gene polymorphisms and serum 25hydroxyvitamin D level in Egyptian female patients with systemic lupus erythematosus. Mol Biol Rep., 40:615162.

23. Mosaad Y, Hammad E, Fawzy Z et al. (2014): Vitamin $\mathrm{D}$ receptor gene polymorphism as possible risk factor in rheumatoid arthritis and rheumatoid related osteoporosis. Human Immunology, 75:452-461.

24.Saad M, Mabrouk M, Eldeib A et al. (2015): Genetic case-control study for eight polymorphisms associated with rheumatoid arthritis. PLoS One, 10(7):13-60. 